\title{
The Application of Lean Management in the Management of the Psychiatric Care System in the Regional Model of Psychiatric Care in Denmark (the Region of Zealand)
}

\author{
Iwona Mazur ${ }^{1}$, Anna Depukat ${ }^{2}$, Joanna Jończyk ${ }^{3}$, \\ Piotr Karniej ${ }^{1}$
}

1 Department of Public Health, Division of Organization and Management, Wroclaw Medical University, Poland

2 Joseph Babinski Psychiatry University Hospital in Krakow, Poland

3 Department of Organization and Management, Faculty of Engineering Management, Bialystok University of Technology, Poland

\begin{abstract}
The aim of the article is to present the application of the lean management method as appropriate for the management of the organizational system of psychiatric care in the Zealand region of Denmark. The organizational solutions of the Danish psychiatric care system presented in this paper are individualized and adapted to the regional needs of the residents. In Denmark, there are five administrative regions, in which each independently organizes its own system of medical (psychiatric) care. This means that the regions have considerable independence in choosing the acceptable and necessary methods of management, including - as is clear from the conducted research - the use of methods put-upon other areas of economy. Although the national laws in Denmark define certain conditions and guidelines for the functioning of psychiatric care (e.g. regarding the use of direct coercion/restrains for patients treated in the centres), there is a distinct separation of structures and methods of functioning throughout the whole country, which constitutes unique observation material from the cognitive point of view. The authors of this paper conduct extensive research and analyse the systems of psychiatric care organizations in various countries (including Spain, Italy and Japan) and, as a result, the obtained results may lead to the selection of the best models from other systems (good organizational practices and management, the management methods in use), which can be applied in the currently reorganised system of the Polish psychiatric care. The choice of Denmark for the observational study is not accidental and is related not only to the fact that there is a large degree of systemic identity within the country and between the regions, but also because the country applies solutions addressed to patients with very different cultural conditions and needs, resulting from their descent, religion, and (world)-views. Denmark is one of those European countries that express a significant acceptance of diversity and tolerance, which is why communities with very different imponderables, denominations, and worldviews co-exist. In the area related to the organization of the psychiatric system, these conditions are of key importance. In the period
\end{abstract}


from January 2015 to December 2017 the authors participated in study visits in Denmark, conducting research aimed at identifying the key success factors of the psychiatric care organization system in the country. The conducted analysis is also based on the analysis of literature and own and participant observations. The conclusions concerning this subject are also the result of interviews conducted with employees of the visited hospitals and system users, both professionals and patients. As the search for an optimal organizational model of psychiatric care is currently an ongoing concern in Poland, it seems justified to review the existing solutions in Europe and perform their critical analysis. A comparison of the adopted solutions was performed, in the context of, above all, the improvement of the quality of these services, their availability, and the satisfaction of patients and their families from the proposed organizational changes. The economic benefits of these solutions are also significant.

\section{Introduction}

Since the mid-20th century, the organization of psychiatric care has been gradually changing in all European countries. In most of these countries, the model of large psychiatric hospitals, located mostly outside the city (which dominated at the beginning of the 20th century), is transformed into the model of environmental care, in which the emphasis is on medical services available in local patients' communities. Both the observations of treatment outcomes and economic analyses of such a model of healthcare point to the importance of transformations towards a coordinated environmental care, focused strictly around the patient in his or her living environment. One of the current dilemmas, and also challenges, of psychiatric care systems in Europe is reorganization of the inefficient and dispersed system consisting in providing individual, uncoordinated services that do not bring an added value, do not lead to an improvement of the whole system, and - most importantly - are unacceptable from the point of view patients, failing to improve their health. In many European countries, entities providing psychiatric services function in difficult organizational and legal conditions, whereas specific legal solutions that could improve the quality of care have not been adopted anywhere. The organizational system of psychiatric care is often archaic in terms of its financing, as the model of contracting individual medical or psychological services, advice and consultations in use in many countries (including Poland) is not conducive to comprehensive provision of benefits and does not enable coordination of patient care on by interdisciplinary teams of specialists. The solutions currently being developed in Poland, based on the coordinated psychiatric care model focused around a mental health centre, seem to change this reality, but what needs to be remembered is its pilot nature and the currently moder- 
ate impact on the whole system and the results of therapeutic treatment on the macro level. In Poland, there is a lack of interdepartmental coordination between the structures of medical care and social support, which translates into radically impaired communication (Stępniewski, 2014) between social workers and doctors, nurses, and psychologists. This lack of coordination also extends to the justice system (adjudication of compulsory isolation), education (school pedagogues, vocational counsellors) and, finally, the police. If misunderstood, the postulated and partially implemented process of deinstitutionalisation of psychiatric care in Poland may lead to a simple dehospitalisation, which - as results from global research - is associated with high risk of homelessness, an increase in the number of suicides, transinstitutionalisation (towards social welfare institutions) or placement of people suffering from mental illness in prisons or centres of forensic psychiatry (WHO, 2008).

For comparison, in most Western European countries in 1990-2012, the total number of psychiatric beds decreased, but the number of beds in the field of forensic psychiatry increased (Chow \& Priebe, 2016). This fact might be disturbing and should be the subject of further research in this area. Poland is currently facing challenges: which direction should we go? How to change the psychiatric care system using the available resources? Where to obtain and effectively use the medical personnel available within the system and how to organize the training system of this personnel? To emphasize how important the organization of psychiatric care is, it is worth recalling the data that shows the scale of the problem. Every fourth Pole has a significant episode of a mental disorder during their lifetime, while approx. $20 \%$ of disability-related expenditure associated with the disease are generated by psychological problems (which is about $4 \%$ of the total GDP) and from the national perspective, mental disorders are responsible for $12 \%$ of the disability rulings in the group of people aged 15 to 59 (CSO, 2016). The costs incurred by the families of mentally ill people are also frequently disregarded.

The lean management method used in this paper as the basis for reducing unnecessary system activity on the one hand, and lowering the costs of psychiatric care activities on the other, seems to suit the needs of a system suffering from a scarcity of resources best. Previous research on the Danish psychiatric model (Dammand et al., 2014) proves that lean management can be successfully used in the organization of medical care. The present paper describes one of the organizational and functional models in Europe that could be an inspiration for a reform of the Polish system of medical care in psychiatry. 


\section{Aim of the Study}

The purpose of this report is to present the lean management model as a support tool for the psychiatric care organization system in the Zealand region of Denmark. The complementary purpose is to identify the good practices used by the Danish psychiatric care system that can be adapted in Poland, in connection with the ongoing reorganization of psychiatric care.

\section{Material and Method}

This paper uses the following research methods: literature query, desktop analysis (analysis of strategic documents and primary and secondary source data, including the Strategy of the region of Zealand, quality objectives in health care in Denmark, internal documents provided by hospitals and other organizations providing psychiatric services in Denmark), participant observation, IDI (Individual Deep Interview), and focus groups. The applied research methodology is typical in the case of observational and analytical research, serves to identify the key research factors, and is a source of further resultant inference.

\section{Discussion}

Denmark is a country inhabited by a population of 5,748,000 (https:// countryeconomy.com/demography/population/denmark). Since January 1, 2007, Denmark is divided into five regions, which are further subdivided into 98 municipalities. In Denmark, psychiatric care is a public task organized and financed by regional authorities. In practice, this means that the responsibility for the psychiatric care of residents is transferred regionally to municipalities. Regional centres of environmental psychiatric care, which provide services at the basic, specialist, and highly specialized levels - both medical and social - have initialized regional development. In addition, the placement of psychiatric care within the system implies cooperation between clinical and environmental psychiatry (in Denmark also in social terms) and psychiatric care. There are no institutional forms of social assistance in Denmark.

The main centres are located in large cities. There are also local centres for environmental psychiatric care in smaller towns. Psychiatric beds are available in 30 units (departments at general hospitals and psychiatric hos- 
pitals cooperate with multi-specialist hospitals). In 2017, there were 2,739 beds available in Denmark and 118,697 patients used them with the average duration of hospitalization of 16 days (Turnpenny et al., 2017). Emergency care in urgent cases is available through emergency rooms in psychiatric hospitals or general hospitals. Psychiatric care is essentially free and the private sector in this area is more concerned with cooperation with business on the basis of the "triple helix" model, i.e. generation of knowledge between three types of entities: research centres, the industry, and the government (including local government institutions). Currently, the funds allocated for psychiatric care cover the financing of not only treatment but also other essential needs of psychiatric patients, e.g. broadly understood social support (help in aligning life, living, work, and supplementary education) and minimizing the limitations related to disease, social integration, prevention of discrimination and violation of rights. In Denmark, "protected" dwellings located in communes are available for mentally ill people (both temporary and permanent residences), with approx. 2,500 patients using them annually (Andreasen, n.d.). What is very important in the country is the longstanding tradition of "folk schools" inscribed in broadly understood social support (folkehojeskole provides rural residents with access to culture, education, and development and plays the role of "schools of life" that teaches society members to live in a creative way and cooperate), owing to which the idea of support and self-help activity is close to the citizens of Denmark.

The regions in Denmark differ slightly regarding the organization of care, e.g. in the capital region, where there is greater access to specialist services in the field of psychiatry. In other regions, patients and their families, when asked to indicate system weaknesses, describe the limited access to psychotherapy (especially long-term). Long-term psychiatric care centres are not available in Denmark. In the Central Jutland region, due to the special care for the non-stigmatization of the mentally ill, a decision was made to organize joint admission rooms for mentally and somatically ill patients whereas trained guards (Rangers) provide broadly understood support and help in crisis and health situations (including people with mental disorders). In addition, open clinics for detained patients are organized in the city of Viborg (the same region). Detailed organizational solutions are always decided by the region's authorities.

The Zealand region is one of the five regions of Denmark, consisting of 17 municipalities over an area of $7,273 \mathrm{~km}^{2}$. The area's population living is 821,000 residents (budget of 17 billion DDK). What is important as far as the main regional development strategies are concerned are regional development and efficient enterprises in the area of health protection and 
social support. Far from being an empty record, the strategy is actually actively implemented, which is visible at every step. The vision of the region of Zealand is to create friendly conditions and infrastructure to enable continuous growth and guarantee the best possible quality of life for its residents. Conversations taking place in the Commune Office clearly emphasize cooperation, both at the level of municipalities and through the agreement between authorities. The agreement is in writing and defines the responsibilities and rules of cooperation between the region's authorities, hospitals and health experts. An important assumption is to determine the strategy and health policy for the entire region and to implement subsequent planned elements, including current analyses. The data in the region of Zealand is treated as a powerful resource and gives the opportunity to conduct innovative research in all areas of medicine, which is a source of pride both for local authorities and system users. Through these analyses, psychiatry was identified as one of the areas requiring priority development, high risk areas were indicated (the Act on Equal Treatment was passed), and a coherent policy was implemented in order to improve the provision of a comprehensive offer and infrastructure through a more efficient use of the available staff resulting from a reorganizations of their current availability. In order to improve staff availability, nurse assistants and psychologists' specialization in the field of clinical psychiatry (which significantly increases competence and responsibility as well as the ability to make treatment decisions) were introduced. These changes enable real support for psychiatrists and nurses, which Denmark is also struggling with. Moreover, due to the above analyses, among others, a decision was made to build one of the most modern psychiatric hospitals in Europe (Hospital in Slagelse), which took over specialized care as the main hospital of the region. Interestingly, the Slagelse Hospital replaced 4 smaller psychiatric centres and was designed and built using all the currently available innovative methods of construction, with the best adaptation to the needs of psychiatry in mind. In addition, the housing conditions and the penetration of hospital buildings with gardens is in itself a means of stimulation and facilitation of the healing process. Furthermore, the main assumption at the design stage was a reduction in the use of coercive measures and pharmacotherapy. Limiting the use of direct coercion to people with mental disorders is one of the national quality objectives in health care to be pursued by all regions.

At present, the hospital has 190 psychiatric beds and an out-patient section of the environmental centre. The remaining part of psychiatric care is organized very much like in the other regions of Denmark; the burden of treatment is taken by organizations well integrated with the environment, 
owing to which they enable better and faster conditions of recovery. Necessary hospitalizations are short and hospitals are friendly. Local authorities provide a hospital stay where treatment and care is subject to continuous evaluation and takes into account current standards. Moreover, qualified staff ensures the continuation of treatment outside the hospital while living, educational and other services are provided by the given municipalities, which for this purpose maintain day centres, places in nursing homes, finance temporary stays in hostels, and help in the home environment. Using the environmental mental health centre requires a referral, for example, from a primary care practitioner. They are provided with training which improves cooperation with the psychiatric care system. A special mental health fund helps to provide courses and classes in municipalities. What is important, supervision and evaluation mainly concern the quality of services provided. Under the Act, any use of direct coercion measures is reported directly to the Ministry of Health, which publishes the data in an annual report. The psychiatric care network cooperates with seven multi-specialized hospitals located in the region, which provide basic and specialized health care.

An important feature of the organization of psychiatric hospitals is the fact that all work is performed according to the same model. Care in the whole region is organized in the same way and the general administration is located in Slagelse, which is a very interesting solution that could be implemented in Poland.

An organizational innovation based on the idea of eliminating activities that do not add any value is the Academy of peers, i.e. a project that prepares people with the experience in mental crisis to work in therapeutic teams as a support for professionals. Obviously, only some people can perform these functions, but it is extremely important to use their experience in the healing process. In Polish proposals of changes in the functioning of psychiatric care within the mental health centres, employing the so-called "Recovery assistants" is also included. However, there are not enough opportunities to professionally prepare these people for work and no such position is listed in the catalogue of professions, which is another example of how legislative solutions cannot keep up with practice.

In addition, preventive programs are very important for the Danes. They are also developed based on analyses of available data. The emphasis is on chronic diseases (with psychiatry included in this group). A high level of social responsibility allows such groups to be included in the area of priority impacts, as failure to provide care early on is known to lead to long-term health consequences and generate increasingly high social costs. For this reason, many studies conducted in the region in question concern identifying 
risk factors and increasing morbidity. One of the important strategies that, as is clear from the studies performed there, improve cooperation (which is an important issue from the point of view of the effectiveness of treatment) is to establish partner relations with the patient. In addition, many educational programs are conducted in the region, which means that patients and their families assess their quality of life very highly. It is important to co-develop the therapeutic process, i.e. there needs to be a strong focus on including the patient and his/her family in the treatment process.

\section{Lean Management in the Management of Medical Organizations}

Lean management is a derivative of the concept of lean production, or "thinner" production (Stępniewski et al., 2011). The name has American roots and means slenderness and adaptation. This concept was used for the first time in the Japanese automotive company Toyota, although since then it has also had many imitators in the medical care system. The creation of the basic features and assumptions of "lean management" is inherently associated with the development of the management system in the Japanese corporation that lasted for almost 20 years. The economy of Japan, strictly restricted by the United States after the Second World War, operating in conditions of a scarcity of resources (similarly to modern health care or, in particular, psychiatric care), is of great importance here. In such a situation, the car company owner could not allow the waste of resources to spread.

The precursors realized the concept as a result of combining many business management techniques to create a modern system characterized by, among others, the universality of the team and work rotation phenomena, a flat organizational structure, a low degree of formalization and centralization, and continuous employee training. It can be assumed that today's lean management is based on many demands made over the years by specialists in the field of organization and management science (D'Andreamatteo et al., 2015).

The basic assumption of the discussed concept is to avoid all kinds of waste, through a constant improvement of processes in the organization, as well as a reduction of unnecessary functions. It also provides employees with the skills and opportunities to participate in the improvement of connections and flows between workplaces (Czerska \& Szpitter, 2010).

Generally speaking, lean management mainly focuses on three sectors of a given enterprise: 1) costs (Stępniewski \& Mazur, 2005), 2) quality (Stępniewski \& Bugdol, 2013), and 3) human resources (Nęcki \& Kęsy, 
2013). The company applying this method's principles aims to reduce the costs associated with its operation, assumes improvement of the quality of its products and services as well as all the related processes. It also aims to improve the quality of work through appropriate training and, above all, motivation of employees (Buchelt, 2017; Jończyk, 2015).

The use of lean management makes it possible to provide the customer with a product or service that meets their needs, at the lowest possible cost and with the least possible use of resources.

Lean management is a collection of many components that are essential, on the one hand, and facilitate the introduction of this concept, on the other. Some of them also constitute separate management concepts, closely related to lean management. Siemionek and Siemionek-Ruskań (2015) list the following components of lean management: group work, personal responsibility, feedback, customer's interest, value added priority, standardization, continuous improvement, immediate elimination of errors, anticipation, and gradual improvement.

Similar assumptions are presented by K. Zimniewicz (2003), who mentions the following principles: group work, decentralization of decisions, customer orientation, continuous improvement, flattened hierarchy, rejection of errors at source, avoidance of extravagance and waste, continuous flow of materials, TQM, and simultaneous improvements. In many enterprises these elements occur simultaneously, complementing each other. In some cases, the occurrence of one of them is closely correlated with the occurrence of another.

The above analysis shows that lean management is a method that allows to increase the efficiency of teams, improves the quality of the implemented processes and as such can be adapted to medical organizations, which in fact implement very similar - from the organizational point of view - processes, such as: resource management, a production process (providing medical services), and after-sales service. Due to space limitations, only four key elements of lean management are being discussed below: team work, decentralization of decisions and a flattened hierarchy, customer orientation, and kaizen.

Team work. In the literature related to broadly understood business management, the concept of "synergistic effect" can be often encountered. It assumes that cooperation gives greater benefits than the sum of individual activities. This is mainly due to the various employees' points of view on a given problem, i.e. the degree of perception of the whole group is much larger than that of an individual employee. This is very important in the 
context of implementation of lean management. Along with the assignment of a specific task to a group, the responsibility for its implementation is increased. In this way, the group receives greater discretionary power. The level of direct employee control is also reduced with the increasing autonomy of the group contributing to the motivation and readiness of individual participants (Jończyk \& Mazur, 2016).

An example of the use of group work in the Zealand region of Denmark are the regular meetings of department employees together with the necessary persons from outside of the organization (social workers), during which organizational and individual problems concerning the organization and accessibility of care are discussed. These meetings are called "board meetings" and serve to exchange experiences and views between employees regarding a specific organizational problem. Group work in this sense has a significant impact on the improvement of the quality of communication between the participants of the decision-making process, the ability to express their own opinions and views, and the use of techniques to improve the quality of decisions (e.g. brainstorming, substantive discussion, searching for solutions); it also eliminates inefficiency or ineffectiveness from the management process.

Decentralization of decisions and a flattened hierarchy. The high level of group autonomy contributes to the occurrence of decentralization in the company, which is another component of "lean management". In connection with the increase of group responsibility, decisions made in the company are delegated to lower organizational levels. Decentralization of decisions contributes to the elimination of middle management levels, thus flattening the hierarchy in the organization (Mazur et al., 2015). The introduction of decentralization brings many benefits, including better quality of information and shorter times of its transfer between different organizational levels, high flexibility of operation in a changing environment, or the development of initiative in lower-level employees and therefore increased motivation to work (Buchelt, 2017). However, it is important to meet a number of conditions that are necessary to obtain the positive effects. It should be remembered that staff should be informed about all decisions made in the company. Confidence in employees is also important (Jończyk, 2012). Management should be convinced that the decision-makers will be able to make the right choice in changing conditions (Buchelt et al., 2017). Employees' knowledge of the organizational structure, its strategy and basic goals is also fundamental.

An example of the use of the concept of lean management is the large freedom of local structures in the region of Zealand in terms of the possibil- 
ity of using a specific structure and organizational form. Solutions adopted at the regional level are appropriate for the local needs (e.g. whether there is a need for psychiatric care for children, for adults, or for forensic observation), which are consistent with national targets (i.e. reducing the number of judicial isolations, reducing the use of direct coercion).

Customer orientation. Increasing competition on specific markets contributes to the fact that the attitude towards the customer becomes as important as the attitude towards the staff. Many organizations do not realize that clients are the determinant of their existence and their needs should be placed first. Increasingly, the factor determining the achievement of success by the organization is the ability to recognize and satisfy various customer requirements.

Customer orientation is of key importance in psychiatric care because it concerns a very sensitive area of the patient's personal area. Individualization of psychiatric care has many dimensions, ranging from identification of problems with which patients report to the therapist, through the determination of the necessary therapeutic methods, to the use of pharmacotherapy. From the point of view of the whole system in Denmark, including the region of Zealand, the patient is the focus, which has an effect on therapeutic success, patient satisfaction, and care efficiency.

Kaizen - Continuous improvement. "Kaizen" is derived from the Japanese word meaning improvement and change for the better. In literature, kaizen is defined as the philosophy of continuous improvement of business processes, through gradual but constantly introduced improvements in which all the employees of a given company participate. The concept of kaizen is based on five basic rules: 1) repetition of improvement processes is achieved by standardizing the activities performed, as well as by disseminating it through training and work discipline; 2) the process and the results obtained; 3) quality is the first priority; 4) basing activities on reliable data; 5) notice your clients. One of the most important goals resulting from the kaizen method is to provide the client with a product or service that meets their expectations; 6) continuous flow and waste avoidance; 7) quality management; 8) management by objectives. The key elements of this approach include:

- involvement in the program at all levels of management,

- joint setting of goals by managers and subordinates - the principle of participation,

- linking individual goals with overarching strategic goals, 
- precision of formulating the goal,

- autonomy in the implementation of plans,

- assessment of results - periodic employee evaluation.

The basis for the mechanism of continuous improvement of the psychiatric care system in Denmark is the quality model based on Deming wheels (PDCA), and thus the orientation of all employees towards selfimprovement of processes and procedures. This orientation is present at every organizational stage, starting from national structures, where adaptation to changes is common, up to the structure of a psychiatric hospital, where decisions taken in accordance with the concept of quality management are taken on a microscale, in relation to the local system and a particular patient. In Denmark, there is currently a general shift away from processes and procedures, common in Poland, and towards quality philosophy, known (from philosophy and other sources) as "kaizen". The document entitled "National Quality Program for Health 2015-2018" (Gp Access, 2015) adopted at the national level is a governmental strategy for the future quality of work in health care. The core of this program is to create more value for the patient. The program must support the development of health care that provides better quality of care, with emphasis on results that are important to the patient. This aspect is crucial for the lean management model because it is based directly on the concept of eliminating phenomena that do not bring benefits. This model is to be anchored in a uniform quality improvement program for the entire country. The key areas of this model were the improvement of the health of the population, a high perceived and experienced quality of medical care, and low costs of citizens' treatment.

\section{Conclusions}

The model of the Danish psychiatric care in the region of Zealand is a very good example of actions to improve the quality and effectiveness of care, while striving to improve quality, reduce its costs, and significantly improve the perception of quality in society. Such goals are certainly unachievable in many countries (including Poland); the state of satisfaction of patients with health care in Denmark being evidenced by its high position in health satisfaction surveys. In the Danish psychiatric care system, attention is paid to strong regionalization of health care and psychiatric care in particular, which allows the use of individually selected management tools and locally focused centres of gravity, based on local maps of health needs. Attention is drawn to the fact that psychiatric care is a separate element 
of the system, which covers the functioning of psychiatric hospitals and general hospitals.

Danes attach great importance to the process of involving patients and their families in the therapeutic process, which is an expression of individualized care, patient orientation, and eliminating unnecessary expenditures on inefficient or ineffective methods of treatment. Patients and their families become co-designers in the process of patient care. The focus is on broadly understood cooperation, not only with social assistance and family doctors or specialist doctors but also with non-governmental organizations (NGOs) and stakeholders in the public management system (municipality, region, government institutions). To improve the exchange of information, special meetings are organized both in environmental centres and hospitals. In a situation when difficulties are identified, new solutions are sought. For example, in connection with difficult cooperation with family doctors, it was decided to appoint a coordinator of family doctors, who is additionally reimbursed for improving cooperation and the related activities and supervising the flow of information about patients.

A comparison between the Danish model with the attempts to reorganize the Polish model of psychiatric care would indicate the need to focus on elements such as: cooperation, coordination and consistent implementation of an objectively justified strategy. The model of functioning of the psychiatric care in the Zealand region of Denmark, presented in this paper, is a good example of the effectiveness of system management in general, in particular the psychiatric care system. It is also an example of many good practices that, when applied in Poland, may contribute to improving the quality of care for patients with mental disorders.

\section{Acknowledgements}

The study described in this report was carried out as part of the ST.E140.16.056 project implemented by the Medical University of Wroclaw as part of the statutory research of the Department of Public Health.

\section{R E F E R E N C E S}

Andreasen, H. (n.d.). The OPUS Project: Clinical treatment and research in Copenhagen, Denmark. Retrieved from https://www.ispn-psych.org/assets/docs/ opus_project.pdf

Buchelt, B. (2017). Koncepcja systemu zarzadzania efektywnościa pracy personelu medycznego w szpitalach. Kraków: Wydawnictwo Uniwersytetu Ekonomicznego w Krakowie. 
Buchelt, B. I., Frączkiewicz-Wronka, A., \& Kaminska, R. (2017). Key determinants of human resource management in hospitals: stakeholder perspective. Engineering Management in Production and Services, 9(2), 105-115.

Chow, W. S., \& Priebe, S. (2016). How was the extent of institutional mental healthcare changed in Western Europe? Analysis of data since 1990. BMJ Open, 6(4): e010188. doi: 10.1136/bmjopen-2015-010188

CSO (2016). Health Status of Population in Poland in 2014. Warsaw: Central Statistical Office.

Czerska, M., \& Szpitter, A. (2010). Koncepcje zarzadzania. Podręcznik akademicki. Warszawa: C.H. Beck.

D’Andreamatteo, L., Ianni, L., Lega, F., \& Sargiacomo, M. (2015). Lean in healthcare: A comprehensive review. Health Policy, 119(9), 1197-1209.

Dammand, J., Hørlyck, M., Jacobsen, T. L., Lueg, R., \& Röck, R. L. (2014). Lean management in hospitals: Evidence from Denmark. Administratie si Management Public, 23, 19-35.

Gp Access (2015). National Quality Program for Health 2015-2018. Retrieved from https://gpaccess.uk/wordpress/wp-content/uploads/2015/04/NATIONALQUALITY-PROGRAM-FOR-HEALTH-2015-2018.html

Jończyk, J. (2012). Modelowanie kultury organizacyjnej w zakładach opieki zdrowotnej. In Ł. Sułakowski \& R. Seliga (Eds.), Kulturowe determinanty zarzadzania szpitalami w Polsce. Warszawa: Difin.

Jończyk, J. (2015). The Impact of Human Resource Management on the Innovativeness of Public Hospitals in Poland. Procedia - Social and Behavioral Sciences, 213, 1000-1007.

Jończyk, J., \& Mazur, I. (2016). Rola zespołów we wdrażaniu zmian w zarządzaniu psychiatryczną opieką zdrowotną. In Ł. Sułkowski, A. Noworól, \& B. Mazurek-Kucharska (Eds.), Przedsiębiorczość i Zarzadzanie (Vol. 17(7(1)), pp. 439-451). Wydawnictwo Społecznej Akademii Nauk.

Mazur, I., Karniej, P., \& Jończyk, J., (2015). Zdrowie psychiczne. Organizacja Zarzadzanie - Standardy. Wrocław: Wydawnictwo Cedu.

Nęcki, Z., \& Kęsy, M. (2013). Postawy personelu medycznego wobec zarzadzania szpitalem. Kraków: Wydawnictwo Uniwersytetu Jagiellońskiego.

Siemionek, A., \& Siemionek-Ruskań, M., (2015). Instrumenty zarządzania współczesnym przedsiębiorstwem. Kwartalnik Kolegium Ekonomiczno-Społecznego. Studia i Prace, 3 (Vol. 5(23), Finanse przedsiębiorstw), 97-107.

Stępniewski, J. (2014). Francuski model systemu komunikacji szpitala. Istota, narzedzia, wyzwania. In T. Goban-Klas (Ed.), Komunikowanie w ochronie zdrowia - interpersonalne, organizacyjne $i$ medialne (pp. 98-106). Warszawa: Wolters Kluwer.

Stępniewski, J., \& Bugdol, M., (2013). Costs, organization and management of hospitals. Cracov: Jagiellonian University Press. 
Stępniewski, J., Karniej, P., \& Kęsy, M. (2011). Innowacje organizacyjne w szpitalach. Kraków: Wolters Kluwer.

Stępniewski, J., \& Mazur, I. (2005). Koszty i ich rola w zarządzaniu zakładami opieki zdrowotnej. In J. Stępniewski (Ed.), Zarzadzanie szpitalem - kompendium menedżera. Wrocław: Wydawnictwo Uniwersytetu Medycznego we Wrocławiu.

Turnpenny, A., Petri, G., Finn, A., Beadle-Brown, J., \& Nyman, M. (2017). Mapping and understanding exclusion: Institutional, coercive and community based services and practices across Europe. Brussels: Mental Health Europe.

WHO (2008). Policies and practices for mental health in Europe - meeting the challenges (WHO Report). Retrieved from http://www.euro.who.int/_data/ assets/pdf_file/0006/96450/E91732.pdf

Zimniewicz, K. (2003). Współczesne koncepcje i metody zarzadzania. Warszawa: PWE. 